\title{
Inhibition of Gabrp reduces the differentiation of airway epithelial progenitor cells into goblet cells
}

\author{
AN WANG $^{1 *}$, QIUYANG ZHANG ${ }^{2 *}$, YONGMEI WANG ${ }^{3 *}$, XUE LI $^{2}$, KUAN LI $^{2}$, \\ $\mathrm{YU} \mathrm{LI}^{2}$, JIANHAI WANG ${ }^{2}, \mathrm{LI} \mathrm{LI}^{4}$ and HUAIYONG CHEN ${ }^{1,2,5}$

\begin{abstract}
${ }^{1}$ Department of Basic Medicine, Haihe Clinical College of Tianjin Medical University; ${ }^{2}$ Key Research Laboratory for Infectious Disease Prevention for State Administration of Traditional Chinese Medicine, Tianjin Institute of Respiratory Diseases; Departments of ${ }^{3}$ Pathology and ${ }^{4}$ Respiratory Medicine, Tianjin University Haihe Hospital;

${ }^{5}$ Tianjin Key Laboratory of Lung Regenerative Medicine, Tianjin 300350, P.R. China
\end{abstract}

Received September 4, 2020; Accepted March 12, 2021

DOI: $10.3892 /$ etm.2021.10152

\begin{abstract}
Bronchial asthma is an intractable pulmonary disease that affects millions of individuals worldwide, with the overproduction of mucus contributing to high morbidity and mortality. Gamma-aminobutyric acid (GABA) is associated with goblet cell hyperplasia in the lungs of primate models and Club cells serve as airway epithelial progenitor cells that may differentiate into goblet and ciliated cells. In the present study, it was investigated whether the GABAA receptor pi (Gabrp) is essential for Club cell proliferation and differentiation in mice. Validation of microarray analysis results by reverse transcription-quantitative PCR (RT-qPCR) demonstrated that Gabrp is highly expressed in mouse Club cells. Predominant expression of Gabrp in mouse Club cells was further confirmed based on naphthalene-induced Club cell injury in mice, with organoid cultures indicating significant reductions
\end{abstract}

Correspondence to: Professor Huaiyong Chen, Department of Basic Medicine, Haihe Clinical College of Tianjin Medical University, 890 Jingu Road, Tianjin 300350, P.R. China

E-mail: huaiyong.chen@foxmail.com

Professor Li Li, Department of Respiratory Medicine, Tianjin University Haihe Hospital, 890 Jingu Road, Tianjin 300350, P.R. China

E-mail: lily20060718@163.com

*Contributed equally

Abbreviations: GABA, gamma-aminobutyric acid; Gabrp, GABAA receptor pi; BMI, bicuculline methiodide; CFE, colony-forming efficiency; Scgbla1, secretoglobin family 1A member 1; FACS, fluorescence-assisted cell sorting; AT2, alveolar type 2; PTEN, phosphatase and tensin homolog; IL, interleukin; PNEC, pulmonary neuroendocrine cell; HBSS, Hank's balanced salt solution; AHR, aryl hydrocarbon receptor; TGF, transforming growth factor

Key words: asthma, goblet cells, Gabrp, airway progenitor cells, proliferation, differentiation in the organoid-forming ability of mouse Club cells in the presence of Gabrp antagonist bicuculline methiodide (BMI). Furthermore, the RT-qPCR results indicated that the mRNA levels of chloride channel accessory 3, pseudogene (Clca3p), mucin (Muc)5Ac and Muc5B were significantly decreased in BMI organoid cultures. These results suggested that blocking GABA signaling through Gabrp inhibits mouse Club cell proliferation, as well as differentiation into goblet cells. Therefore, targeting GABA/Gabrp signaling may represent a promising strategy for treating goblet cell hyperplasia in bronchial asthma.

\section{Introduction}

Bronchial asthma is an intractable pulmonary disease associated with bronchial smooth muscle hyperresponsiveness, damage of airway epithelium and continuous inflammation in the airways of patients (1-3). At the steady state, the intrapulmonary epithelium serves as a barrier against inhaled microbes and pollutants and is essential for maintaining lung homeostasis. Club cells are characterized as abundant, discrete, electron-dense granules and represent important secretory cells residing in the conducting epithelium that respond to environmental insult through the release of biologically active factors, including secretoglobin family $1 \mathrm{~A}$ member 1 (Scgbla1, also called as CCSP), Scgb3a1, Scgb3a2, mucins (Muc), lactotransferrin, cytokines and chemokines (4-7). Club cells either exhibit antibacterial activity or recruit immune cells to the airways to clear foreign substances (7).

Constant foreign challenge (either inhaled particles or pathogens) are able to damage the pulmonary epithelium and result in damage closely related to that of lung diseases (8). Epithelial shedding is a commonly described event in bronchial asthma, respiratory infections, chronic bronchitis, fibrosis and interstitial lung disease (9-11). After lung injury, rapid regenerating programs, including the proliferation and differentiation of regionally distributed epithelial progenitor cells, are necessary to maintain a protective barrier. In the conducting airway, Club cells are commonly considered progenitors for goblet cells and ciliated cells $(12,13)$. Club cells are distributed in the conducting airway epithelium from 
the proximal to distal axis in both humans and mice $(14,15)$. Furthermore, in humans, Club cells substantially contribute to the proliferation of airway epithelium and represent an important cell population involved in maintaining the normal epithelium, particularly the bronchiolar epithelium (15). Therefore, it is essential to reveal the mechanisms underlying Club cell function.

Gamma-aminobutyric acid (GABA) is known to have a crucial role in modulating the function of inhibitory synaptic activity. GABA is also produced by lung cells, including pulmonary neuroendocrine cells (PNECs) (16). Song et al (17) established hereditary tracking mice and demonstrated that PNEC cells are able to differentiate into Club cells and ciliated cells, but that the selective killing of PNECs does not affect the regeneration of Club cells. Therefore, it is possible that PNECs communicate with Club cells during airway epithelial regeneration. In addition, Barrios et al (16) discovered that PNECs secrete GABA and induce goblet cell hyperplasia in primate models. There are two types of GABA receptors, namely ligand-gated ion channels GABAA and $G$ protein-coupled receptors GABAB. GABAA receptor pi (Gabrp) is a member of the GABAA receptor family and reportedly present on airway and/or alveolar epithelial cells (16). However, it has remained elusive whether GABA regulates the differentiation of Club cells into mucus-secreting goblet cells in the lung.

In the present study, Club cells from mouse lung tissue were isolated using fluorescence-activated cell sorting (FACS), transcriptome analysis was performed and an in vivo naphthalene-induced lung injury model was established to confirm that Gabrp is highly expressed in Club cells. Furthermore, organoid culture of Club cells indicated that inhibition of Gabrp activity with bicuculline methiodide (BMI) blocked Club cell proliferation and goblet cell differentiation. These results suggested a possible role for GABA signaling in airway epithelial regeneration and mucus production.

\section{Materials and methods}

Reagents. Biotin-conjugated CD31 antibody (cat. no. 13-0311-85), biotin-conjugated CD34 antibody (cat. no. 13-0341-85), biotin-conjugated CD45 antibody (cat. no. 13-0451-85), phycoerythrin (PE)-cyanine 7 (Cy7)conjugated epithelial cell adhesion molecule (EpCAM) antibody (cat. no. 118216), allophycocyanin (APC)-conjugated stem cell antigen (Sca)-1 antibody (17-5981-81), PE-conjugated CD24 antibody (cat. no. 12-0242-83) and APC-Cy7-conjugated streptavidin (cat. no. 47-4317-82) were purchased from eBioscience. BMI was purchased from Sigma-Aldrich (Merck KGaA). The IQ ${ }^{\text {TM }}$ SYBR Green PCR kit was from Bio-Rad Laboratories, Inc. and SB431542 from Ascent Scientific LLC.

Mice. Wild type mice (purchased from SPF (Beijing) Biotechnology Co., Ltd.) were maintained under specific pathogen-free conditions at the animal facility of Tianjin University Haihe Hospital (Tianjin, China). They were kept under a 12-h light/dark cycle with free access to food and water. A total of 60 male mice aged between 8 and 16 weeks and weighing 22-24 g were used for in vitro culture experiments and in vivo lung injury experiments. Scgbla1-CreER ${ }^{\text {TM }}$;
Rosa26-mTmG (Scgb1a1-mT/mG) mice were established by mating Scgbla1-CreER ${ }^{\mathrm{TM}}$ (Jackson Laboratory) and Rosa26

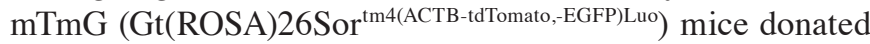
by Dr Ning of Nankai University. The naphthalene injury experiment was performed as described previously (18): Ageand sex-matched mice were injected intraperitoneally with or without $250 \mathrm{mg} / \mathrm{kg}$ naphthalene (Thermo Fisher Scientific, Inc.) dissolved in corn oil (Sigma-Aldrich; Merck KGaA). At days 0,3 and 10 post-injection, mice (day $0, n=10$; day 3, $\mathrm{n}=8$; day $10, \mathrm{n}=10$ ) were euthanized with an overdose of pentobarbital sodium (150 mg/kg, intraperitoneally) and lung tissues were collected for gene expression analysis. All mice were treated with strict adherence to the protocol approved by the Haihe Hospital Animal Care and Use Committee (Tianjin, China; no. 2020HHSQKT-001).

FACS. Preparation of the cell suspension for FACS was performed as previously described (19). In brief, lung epithelial cells were isolated by elastase digestion and resuspended in Hank's balanced salt solution (HBSS) + buffer (HBSS supplemented with $2 \%$ fetal bovine serum, $0.1 \mathrm{mM}$ EDTA, $10 \mathrm{mM}$ HEPES, $100 \mathrm{IU} / \mathrm{ml}$ penicillin and $100 \mu \mathrm{g} / \mathrm{ml}$ streptomycin). Primary antibodies, including biotin-conjugated CD31 antibody (1:40), biotin-conjugated CD34 antibody (1:15), biotin-conjugated CD45 antibody (1:70), PE-Cy7-conjugated EpCAM antibody (1:50), APC-conjugated Sca-1 antibody (1:100) and PE-conjugated CD24 antibody (1:25), were added to the cell suspension, and biotin-conjugated antibodies were identified by incubating cells further with APC-Cy7-conjugated streptavidin (1:100). Dead cells were removed by using 7-amino-actinomycin D (FACS Aria III; BD Biosciences).

Microarray analysis. The sorted epithelial cells were lysed using an RNeasy Mini kit (Qiagen $\mathrm{GmbH}$ ) to isolate RNA. The amount of RNA was determined using a NanoDrop spectrophotometer (Thermo Fisher Scientific, Inc.) and $0.2 \mu \mathrm{g}$ of RNA was used for Affymetrix microarray analysis using mouse genome 4302.0 arrays (Affymetrix; Thermo Fisher Scientific, Inc.). Data were annotated with Affymetrix Expression Console software (Affymetrix, Inc.). GeneSpring GX software (http://www.home.agilent.com/agilent/home. jspx?\&cc=US\&lc=eng; Agilent Technologies, Inc.) was adopted to analyze the differentially expressed genes between groups. Raw data were transformed using a base-2 logarithm $\left(\log _{2} \mathrm{x}\right)$ function to calculate the fold change between two groups. Significantly differently expressed genes were defined as those fulfilling a Student's t-test $\mathrm{P}<0.05$ and a threshold number of misclassifications of $\leq 1$. Treeview software (v.1.6; https://treeview.software.informer.com/1.6/) was adopted to generate heatmaps of gene expression and pathway analysis was performed using the online Gather Kyoto Encyclopedia of Genes and Genomes analysis database (KEGG; http://gather. genome.duke.edu/).

Organoid culture. The MLg2908 mouse lung fibroblast cell line CCL-206 (American Type Culture Collection) was cultured in Dulbecco's modified Eagle's medium (DMEM) (Gibco; Thermo Fisher Scientific, Inc.)_ with $10 \%$ fetal bovine serum (Gibco; Thermo Fisher Scientific, Inc.). In vitro organoid 
Table I. Sequences of primers for PCR.

\begin{tabular}{lll}
\hline Gene & \multicolumn{1}{c}{ Forward primer } & \multicolumn{1}{c}{ Reverse primer } \\
\hline$\beta$-actin & 5'-GGCCAACCGTGAAAAGATGA-3' & 5'-CAGCCTGGATGGCTACGTACA-3' \\
Scgb1a1 & 5'-ATCAGAGTCTGGTTATGT-3' & 5'-ATCCACCAGTCTCTTCAG-3' \\
FoxJ1 & 5'-AGTGGATCACGGACAACTTCTGCT-3' & 5'-ATCCTTCTCCCGAGGCACTTTGAT-3' \\
Reg3g & 5'-ACACTGGGCTATGAACCCAACAGA-3' & 5'-ACCACAGTGATTGCCTGAGGAAGA-3' \\
Sult1d1 & 5'-TGGAACAACTTGGGTCAGTG-3' & 5'-AAGCTCCATGAATGGTACTCG-3' \\
Iyd & 5'-TGTCATCAAAGCAGCAGGAACAGC-3' & 5'-TTCAGGTCTGTGACCCATCGCTTT-3' \\
Fmo3 & 5'-CAGCATTTACCAATCGGTCTTC-3' & 5'-TGACTTCCCATTTGCCAGTAG-3' \\
Cp & 5'-CCTACAAGGCCTCACAATGCA-3' & 5'-TCATTGCCCATTCCCATCA-3' \\
Casp4 & 5'-AGGCTACGATGTGGTGGTGAAAGA-3' & 5'-TGCCATGAGACATTAGCACCAGGA-3' \\
Gabrp & 5'-AGTCCTGCCTGAGATCTGGA-3' & 5'-AAGGTTGAAGGAGGAATCACC-3' \\
Chn2 & 5'-AGTCCGGTGTTCAGATTGTGGGTT-3' & 5'-TTGTGAGCTTTGACAAGCGTGGTG-3' \\
Igf1R & 5'-GTGGGGGCTCGTGTTTCTC-3' & 5'-GATCACCGTGCAGTTTTCCA-3' \\
Rassf9 & 5'-AGCCAAGGAGTTCAGCTCACTTCA-3' & 5'-AGCCTCAGCTTCCTTTCCTCTGTT-3' \\
Clca3p & 5'-AGAATGAACCCACCACGTCCTGAA-3' & 5'-TCAGATTCACCAGGTTCTGCCCTT-3' \\
Muc5Ac & 5'-AGAATATCTTTCAGGACCCCTGCT-3' & 5'-ACACCAGTGCTGAGCATACTTTT-3' \\
Muc5B & 5'-CATCCATCCCATTTCTACCACAA-3' & 5'-AGGCAACATAGAGTTGCTTTTGG-3' \\
\hline
\end{tabular}

Scgb1a1, secretoglobin family 1A member 1; FoxJ1, forkhead box family member J1; Reg3g, regenerating islet-derived 3 gamma; Sult1d1, sulfotransferase family 1D, member 1; Iyd, iodotyrosine deiodinase; Fmo3, Flavin-containing monooxygenase 3; Cp, ceruloplasmin; caspase 4, Casp4; Gabrp, gamma-aminobutyric acid A receptor pi; Chn2, chimerin 2; Igf1R, insulin-like growth factor I receptor; Rassf9, Ras association domain family 9; Clca3p, chloride channel accessory 3, pseudogene; Muc, mucin.

culture of Club cells in Matrigel has been described previously (19). In brief, fractionated Club cells were mixed with MLg cells in Matrigel basic medium (1:1). The culture medium included DMEM/F12 (Gibco; Thermo Fisher Scientific, Inc.), insulin/transferrin/selenium (Invitrogen; Thermo Fisher Scientific, Inc.), $10 \%$ fetal bovine serum, $100 \mathrm{IU} / \mathrm{ml}$ penicillin, $100 \mu \mathrm{g} / \mathrm{ml}$ streptomycin and $10 \mu \mathrm{M}$ SB431542. The mixture was then loaded into Transwell filter inserts (Greiner BioOne), which were placed in 24-well plates containing the culture medium and cultured in a humidified atmosphere with $5 \% \mathrm{CO}_{2}$ at $37^{\circ} \mathrm{C}$. Resulting organoids were visualized using a Zeiss Axiovert40 inverted fluorescent microscope (Zeiss AG). To inhibit the Gabrp-mediated pathway, the cell culture medium was supplemented with $20 \mu \mathrm{g} / \mathrm{ml}$ of BMI (20-23), and co-cultured for 10 days.

$R N A$ extraction and reverse transcription-quantitative (RT-q)PCR. As described previously $(24,25)$, total RNA was extracted from sorted mouse Club cells or Club cell-derived organoids using a Qiagen RNeasy Mini kit (Qiagen $\mathrm{GmbH}$ ) according to the manufacturer's protocol. The composition of the reaction mixture for reverse transcription was as follows: $5 \mu \mathrm{l}$ 10X PCR buffer, $15 \mu \mathrm{l} \mathrm{MgCl}_{2}, 1 \mu \mathrm{l}$ dNTP, $0.625 \mu \mathrm{l} \mathrm{SSIII,}$ $0.5 \mu \mathrm{l}$ RRI, $1 \mu \mathrm{l}$ hexamers, $21.875 \mu \mathrm{l}$ RNA-free water and $5 \mu \mathrm{l}$ RNA. Transcription was conducted using the following conditions: $25^{\circ} \mathrm{C}$ for $10 \mathrm{~min}, 48^{\circ} \mathrm{C}$ for $40 \mathrm{~min}$ and $95^{\circ} \mathrm{C}$ for 5 min. Quantitative analysis of transcripts was performed with a SYBR Green kit according to the manufacturer's protocol. PCR detection was performed using a Realplex4 real-time PCR System (Eppendorf). Intron-spanning gene-specific primers are listed in Table I. PCR amplification was conducted using the following conditions: Initial denaturation at $95^{\circ} \mathrm{C}$ for $2 \mathrm{~min}$, followed by 40 cycles of $95^{\circ} \mathrm{C}$ for $25 \mathrm{sec}$ for denaturation, $60^{\circ} \mathrm{C}$ for $25 \mathrm{sec}$ for primer annealing and $72^{\circ} \mathrm{C}$ for $20 \mathrm{sec}$ for extension. In the isolated the Club cells and clone samples, the mRNA expression level of the target genes was calculated by the comparative $\mathrm{Ct}$ (threshold cycle) method. $\beta$-actin was used as a housekeeping gene to normalize the amount of RNA in the same sample. Specific $\Delta \mathrm{Ct}$ was calculated as follows: $\Delta \mathrm{Ct}=\left(\mathrm{Ct}_{\beta \text {-actin }}\right)-\left(\mathrm{Ct}_{\text {target }}\right)$; relative expression was defined as $2^{-\Delta \Delta \mathrm{Cq}}(26)$.

Statistical analysis. Data from three or more independent experiments were collected and analyzed and results were presented as the mean \pm standard error of the mean. The significance of differences was assessed using Student's t-test or ANOVA. One-way ANOVA was followed by Tukey's and Bonferroni post hoc tests. $\mathrm{P}<0.05$ was considered to indicate statistical significance.

\section{Results}

Transcriptome analysis identifies Gabrp expression in mouse Club cells. Transcriptome analysis was performed to verify Gabrp expression in Club cells and compare it to the expression in alveolar type 2 (AT2) cells, considered to be alveolar epithelial progenitor cells in mouse lungs. Mouse Club and AT2 cells were fractionated by FACS (Fig. 1A) (19) and stromal cells, endothelial cells and hematopoietic cells were excluded from the analysis by surface staining with CD34, CD31 and CD45 antibodies, respectively. The epithelial $\left(\mathrm{EpCAM}^{+}\right)$population was further segregated into Club cells $\left(\mathrm{CD} 24^{+} \mathrm{Sca}-1^{+}\right)$, 
ciliated cells $\left(\mathrm{CD} 24^{\mathrm{hi}} \mathrm{Sca}^{-1}{ }^{+}\right)$and AT2 cells (CD24-Sca-1 $\left.{ }^{-}\right)$. Microarray analysis of Club and AT2 cells generated unique patterns of gene expression for each cell fraction (Fig. 1B), with 558 transcripts enriched within Club cells and 1,006 transcripts enriched within AT2 cells. The distinct gene signatures between the Club cells and AT2 cells may reflect different signaling pathways that regulate their functions. Ingenuity analysis indicated that $\mathrm{Wnt} / \beta$-catenin signaling and phosphatase and tensin homolog (PTEN) signaling were active in Club cells (Table II), which is consistent with published data $(27,28)$. Furthermore, KEGG pathway analysis indicated that interleukin (IL)-17 signaling and aryl hydrocarbon receptor (AHR) signaling may also be important in regulating Club cell function. In addition, studies report metabolic pathways associated with xenobiotics and glutathione in Club cells, which is consistent with their preferential metabolism of naphthalene $(29,30)$. Other metabolic pathways in Club cells include fatty acid metabolism, glycolysis/gluconeogenesis, arachidonic acid metabolism, propanoate metabolism, pyruvate metabolism, tryptophan metabolism and N-glycan biosynthesis (Table II). By contrast, signaling pathways in AT2 cells include the JAK/STAT, insulin receptor signaling, interferon and granulocyte-macrophage colony-stimulating factor pathways, all of which reportedly regulate AT2 cell specification, proliferation and differentiation during homeostasis or following injury (31-34). Other potential but novel signaling pathways associated with AT2 cells include p21-activated kinase signaling and cell division cycle 42 signaling, which are closely related to cell cycle progression and cell transformation (35). Metabolic pathways in AT2 cells included steroid biosynthesis, liver $\mathrm{X}$ receptor-retinoid $\mathrm{X}$ receptor activation, selenoamino acid metabolism, sphingolipid metabolism and methionine metabolism.

Transcripts enriched in Club cells included palate, lung and nasal epithelium clones, flavin-containing monooxygenase 3 (Fmo3), ceruloplasmin $(\mathrm{Cp})$, regenerating islet-derived 3 gamma (Reg3g) and Muc5B, which have previously been demonstrated to be expressed in Club cells (Table III) (4,36-38). Novel transcripts that may be potential markers for Club cells included Ras association domain family 9 (Rassf9), caspase 4 (Casp4), chimerin 2 (Chn2), sulfotransferase family 1D, member 1 (Sult1d1), insulin-like growth factor I receptor (Igf1R), iodotyrosine deiodinase (Iyd) and Gabrp (Tables III and SI). By contrast, transcripts enriched in AT2 cells included brain-expressed gene 1, EGF-like-domain, multiple 6 (Egfl6), ets variant gene 5 (Etv5), ectonucleoside triphosphate diphosphohydrolase 1, tubulointerstitial nephritis antigen, tetraspanin 8 , leucine-rich repeat LGI family member 2, neuritin 1 and adenylate cyclase 7 (Tables III and SI). Transcriptome analysis suggested that Gabrp is highly expressed in mouse Club cells rather than AT2 cells.

Gabrp expression is diminished during naphthalene-induced Club cell injury. Validation of gene expression by RT-qPCR indicated that in addition to known markers, including Scgbla1, Fmo3 and Cp, Gabrp was also highly expressed in sorted mouse Club cells (Fig. 2). Ciliated cells also express Gabrp, suggesting its potential role in ciliated cell differentiation. Similar to Gabrp, Chn2, Igf1R and Reg3g
Table II. Top canonical pathways potentially associated with mouse Club or AT2 cells.

\begin{tabular}{ll} 
A, Club cells & \\
\hline Rank & \\
\hline 1 & Glutathione metabolism \\
2 & Metabolism of xenobiotics by Cytochrome \\
& P450 \\
3 & LPS/IL-1-mediated inhibition of RXR \\
& function \\
4 & NRF2-mediated oxidative stress response \\
5 & Acute phase response signaling \\
6 & AHR signaling \\
7 & Fatty acid metabolism \\
8 & Glycolysis/Gluconeogenesis \\
9 & Xenobiotic metabolism signaling \\
10 & Propanoate metabolism \\
11 & Arachidonic acid metabolism \\
12 & Pyruvate metabolism \\
13 & Role of osteoblasts, osteoclasts, and \\
& chondrocytes in rheumatoid arthritis \\
14 & Tryptophan metabolism \\
15 & Human embryonic stem cell pluripotency \\
16 & Wnt/ $\beta$-catenin signaling \\
17 & IL-17A signaling in airway cells \\
18 & N-Glycan biosynthesis \\
19 & PTEN signaling \\
20 & IL-17 signaling \\
\hline &
\end{tabular}

B, AT2 cells

Rank Pathways

\begin{aligned} \hline 1 & Steroid biosynthesis \\ 2 & JAK/STAT signaling \\ 3 & LXR/RXR activation \\ 4 & IL-4 signaling \\ 5 & Selenoamino acid metabolism \\ 6 & Breast cancer regulation by stathmin-1 \\ 7 & Graft-versus-host disease signaling \\ 8 & Sphingolipid metabolism \\ 9 & Prolactin signaling \\ 10 & Insulin receptor signaling \\ 11 & PAK signaling \\ 12 & Methionine metabolism \\ 13 & Melanocyte development and pigmentation \\ & signaling \\ 14 & PI3K signaling in B lymphocytes \\ 15 & Cdc42 signaling \\ 16 & Axonal guidance signaling \\ 17 & Interferon signaling \\ 18 & Acute phase response signaling \\ 19 & Autoimmune thyroid disease \\ 20 & GM-CSF signaling \end{aligned}


Table III. Top (1-20) transcripts enriched in Club and AT2 progenitor cells.

\begin{tabular}{|c|c|c|c|c|}
\hline \multicolumn{5}{|c|}{ A, Club $\left(\right.$ Sca- $\left.1^{+} A F^{\text {hi }}\right)$} \\
\hline Probe ID & Gene ID & Gene symbol & $\mathrm{P}$-value & Fold change \\
\hline \multicolumn{5}{|l|}{ Club vs. AT2 } \\
\hline 1420347_at & 18843 & Plunc & 0.025 & 127.4 \\
\hline 1427942_at & 237504 & Rassf9 & 0.016 & 96.4 \\
\hline 1449525_at & 14262 & Fmo3 & 0.020 & 77.4 \\
\hline 1456404_at & 100048332 /// 23794 & Adamts5 /// LOC100048332 & 0.001 & 74.9 \\
\hline 1419699_at & 68662 & Scgb3a1 & 0.024 & 74.0 \\
\hline 1434449_at & 11829 & Aqp4 & 0.004 & 72.5 \\
\hline 1417496_at & 12870 & $\mathrm{Cp}$ & 0.036 & 71.5 \\
\hline 1448872_at & 19695 & $\operatorname{Reg} 3 g$ & 0.016 & 62.1 \\
\hline 1449591_at & 12363 & Casp4 & 0.018 & 59.2 \\
\hline 1428574_a_at & 69993 & Chn2 & 0.004 & 58.2 \\
\hline 1429514_at & 67916 & Ppap2b & 0.001 & 57.1 \\
\hline 1424647_at & 216643 & Gabrp & 0.021 & 55.3 \\
\hline 1427626_at & 74180 & Muc5b & 0.004 & 49.6 \\
\hline 1459894_at & 544963 & Iqgap2 & 0.007 & 42.1 \\
\hline 1457589_at & 270120 & Fat3 & 0.012 & 42.1 \\
\hline 1426147_s_at & 58187 & Cldn10 & 0.011 & 39.5 \\
\hline 1454764_s_at & 105727 & Slc38a1 & 0.024 & 38.3 \\
\hline 1453782_at & 70678 & 3021401C12Rik & 0.017 & 37.0 \\
\hline 1424842_a_at & 231532 & Arhgap24 & 0.006 & 35.0 \\
\hline 1443832_s_at & 20324 & Sdpr & 0.002 & 34.0 \\
\hline
\end{tabular}

B, AT2 (Sca-1')

\begin{tabular}{|c|c|c|c|c|}
\hline Probe ID & Gene ID & Gene symbol & P-value & Fold change \\
\hline \multicolumn{5}{|l|}{ Club vs. AT2 } \\
\hline 1448595_a_at & 19716 & Bex1 & 0.011 & -112.5 \\
\hline 1419332_at & 54156 & Egfl6 & 0.010 & -105.0 \\
\hline 1428393_at & 68404 & Nrn1 & 0.038 & -80.8 \\
\hline 1453586_at & 12495 & Entpd1 & 0.002 & -73.2 \\
\hline 1450082_s_at & 104156 & Etv5 & 0.041 & -64.9 \\
\hline 1455995_at & 215821 & D10Bwg1379e & 0.00004 & -61.4 \\
\hline 1460465_at & 68169 & A930038C07Rik & 0.038 & -59.5 \\
\hline 1424649_a_at & 216350 & Tspan8 & 0.007 & -59.4 \\
\hline 1450065_at & 11513 & Adcy 7 & 0.002 & -58.7 \\
\hline 1450648_s_at & 14961 & $\mathrm{H} 2-\mathrm{Ab} 1$ & 0.001 & -55.1 \\
\hline 1450213_at & 29863 & Pde $7 b$ & 0.003 & -53.4 \\
\hline 1440147_at & 246316 & Lgi2 & 0.002 & -53.0 \\
\hline 1449421_a_at & 246133 & Kcne2 & 0.011 & -50.9 \\
\hline 1418402_at & $100045780 / / / 11492$ & Adam19 /// LOC100045780 & 0.002 & -50.8 \\
\hline 1417111_at & 17155 & Man1a & 0.033 & -50.4 \\
\hline 1456307_s_at & 11513 & Adcy 7 & 0.024 & -49.8 \\
\hline 1418403_at & 100045780 /// 11492 & Adam19 /// LOC100045780 & 0.001 & -49.5 \\
\hline 1416200_at & 77125 & $\mathrm{I} 133$ & 0.025 & -47.2 \\
\hline 1452106_at & 114249 & Npnt & 0.044 & -46.3 \\
\hline 1431808_a_at & 16427 & Itih4 & 0.006 & -43.7 \\
\hline
\end{tabular}

Sca, stem cell antigen; AT2, alveolar type 2 . 

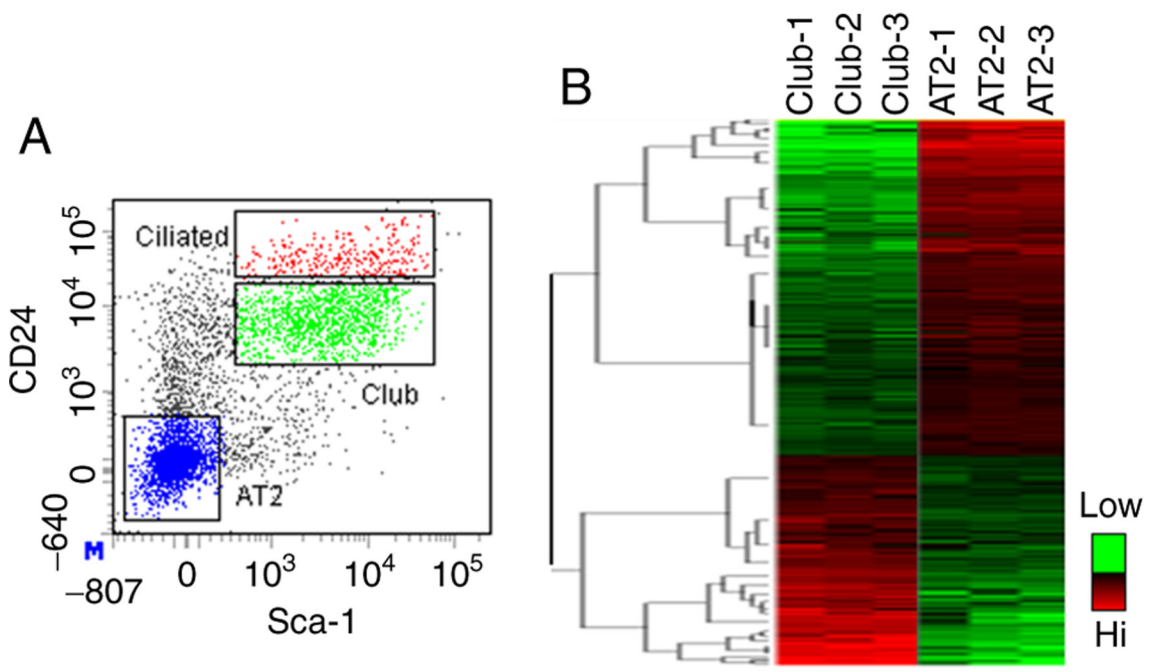

Figure 1. Transcriptome analysis of mouse Club and AT2 cells. (A) Fluorescence-assisted cell sorting. Dead cells were discriminated using 7-amino-actinomycin D stain. Stromal, endothelial and hematopoietic lineages were excluded and epithelial cells were selected for further analysis by Sca-1 expression and CD24. Mouse Club, ciliated and AT2 cells were characterized as CD24+Sca-1+ $1^{+}$CD24 ${ }^{\text {hi }}$ Sca- $1^{+}$and CD24-Sca-1 $1^{-}$populations, respectively. (B) Heatmap displaying the expression pattern of sorted mouse Club cells and AT2 cells. Sca, stem cell antigen; AT2, alveolar type 2.

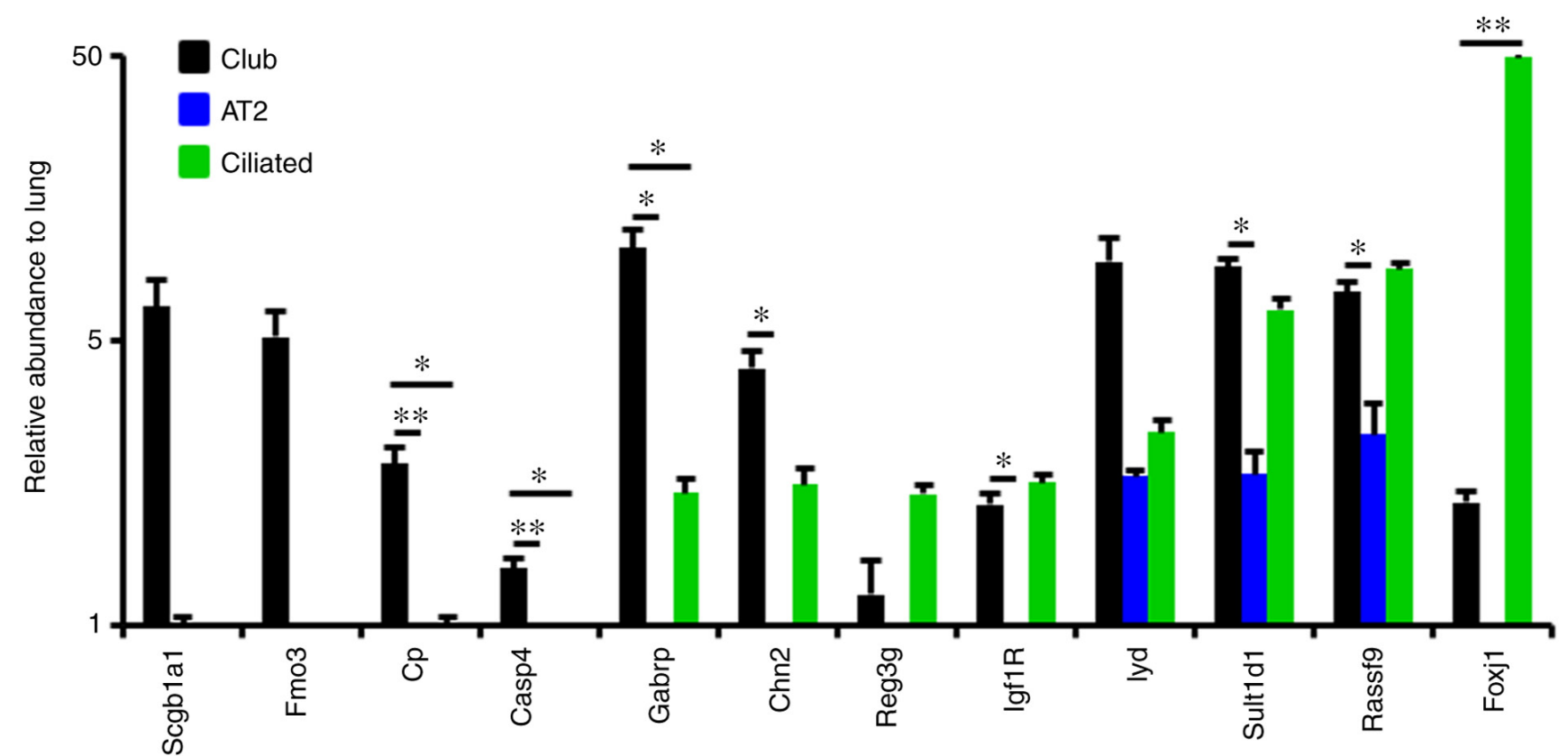

Figure 2. Gabrp is highly expressed in mouse Club cells. The expression of Gabrp and other markers in Club, AT2 and ciliated cells was determined by reverse transcription-quantitative PCR analysis. ${ }^{*} \mathrm{P}<0.05 ;{ }^{* *} \mathrm{P}<0.01$. AT2, alveolar type 2; Scgbla1, secretoglobin family $1 \mathrm{~A}$ member 1; Fmo3, Flavin-containing monooxygenase 3; Cp, ceruloplasmin; caspase 4, Casp4; Gabrp, gamma-aminobutyric acid A receptor pi; Chn2, chimerin 2; Reg3g, regenerating islet-derived 3 gamma; Igf1R, insulin-like growth factor I receptor; Iyd, iodotyrosine deiodinase; Sult1d1, sulfotransferase family 1D, member 1; Rassf9, Ras association domain family 9; FoxJ1, forkhead box family member J1.

were also expressed in ciliated cells (Fig. 2). Although significant levels of Iyd, Sult1d1 and Rassf9 were also observed in Club cells, their expression was not specific to Club cells (Fig. 2).

To verify these results, a Club cell-ablated naphthaleneinjury model in mice was established. Based on studies from our group and others $(18,39)$, naphthalene causes massive loss of Club cells by day 3 ; however, by day 10 , significant recovery of Club cells is observed. Therefore, a window from day 3 to 10 was used to confirm Gabrp expression in Club cells.
Gene-expression analysis of total mouse lungs demonstrated that the expression of Fmo3 and Gabrp had decreased on day 3 after naphthalene injury and then began to recover with time, similar to Scgbla1 expression kinetics (Fig. 3). Furthermore, Lyd and Sult1d1 expression were reduced to a lesser extent relative to Gabrp expression (Fig. 3). These results verified the specific expression of Gabrp in mouse Club cells. and goblet cell differentiation. It was then examined whether 


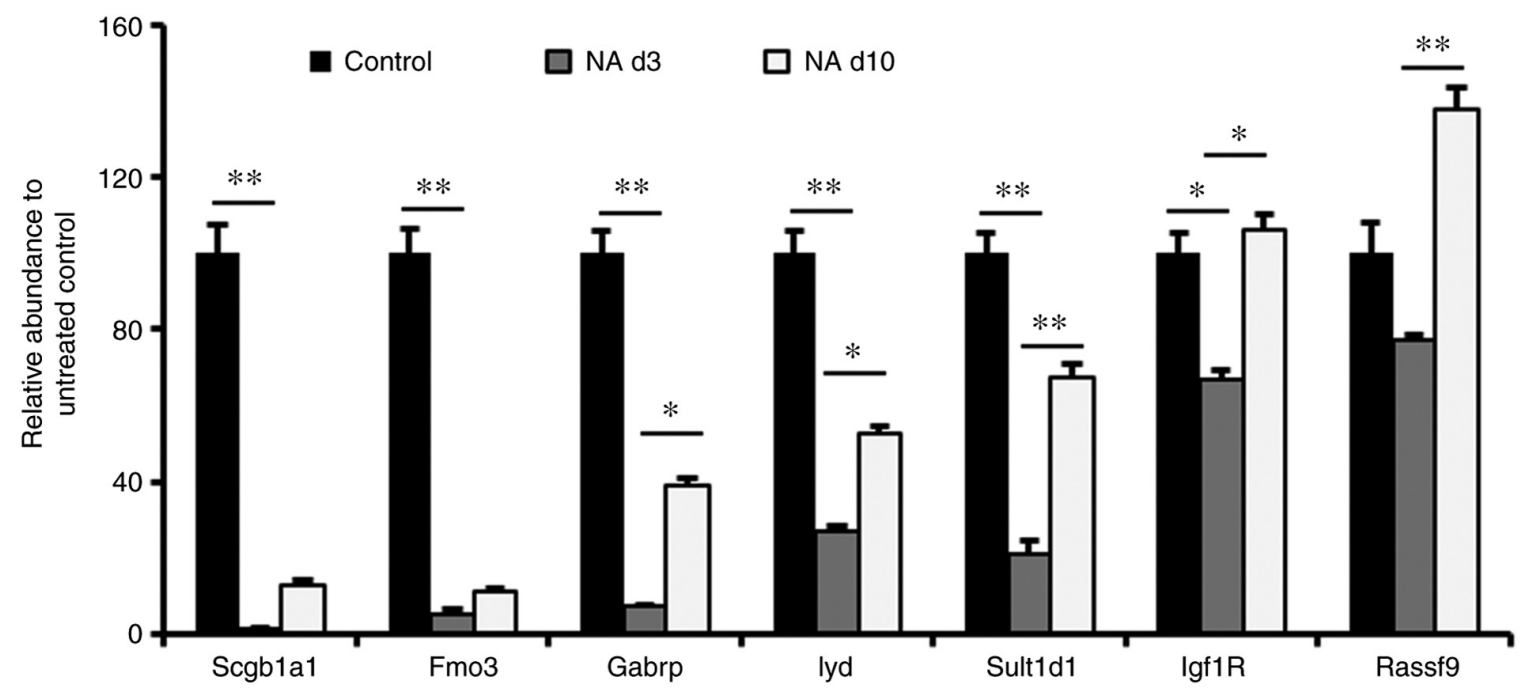

Figure 3. Gabrp expression is reduced in the lung after naphthalene injury. Naphthalene was injected intraperitoneally into mice and lung tissues were harvested to examine the expression of Gabrp and other genes at day 3 or 10 after injury $(\mathrm{n}=8-10)$. ${ }^{*} \mathrm{P}<0.05 ;{ }^{* * *} \mathrm{P}<0.01$. Gabrp, gamma-aminobutyric acid $\mathrm{A}$ receptor pi; Scgbla1, secretoglobin family $1 \mathrm{~A}$ member 1; d, day; NA, naphthalene.

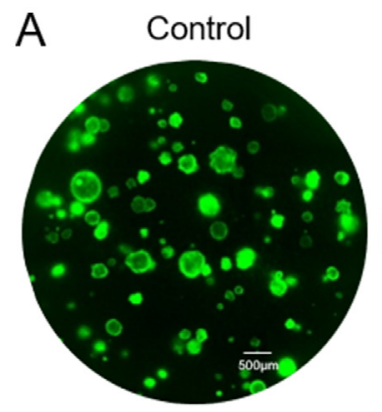

B

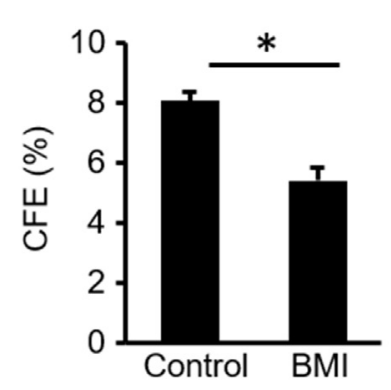

BMI

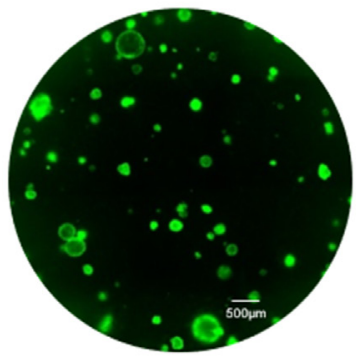

C

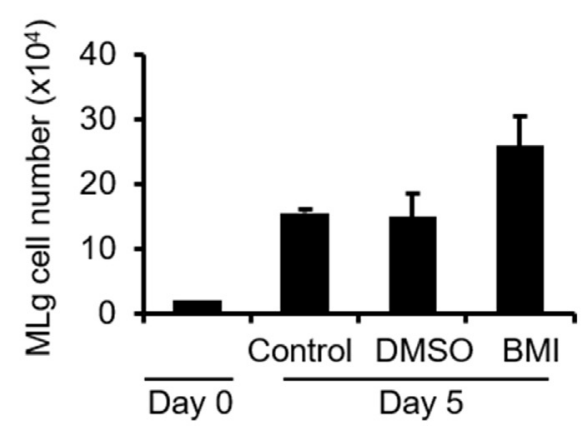

Figure 4. Gabrp inhibition blocks the proliferation of mouse Club cells. (A) Scgbla1-tagged Club cells were isolated from Scgb1a1-mT/mG mice and co-cultured with MLg fibroblasts in the absence (Control) or presence of the Gabrp antagonist BMI. Fluorescence microscopy images displaying green fluorescence protein were captured on day 10 after seeding (scale bar, $500 \mu \mathrm{m}$ ). (B) CFE of control and BMI cultures in A. (C) MLg cells were cultured in the absence or presence of BMI and counted 5 days later. ${ }^{*} \mathrm{P}<0.05$. Gabrp, gamma-aminobutyric acid A receptor pi; Scgbla1, secretoglobin family $1 \mathrm{~A}$ member 1; BMI, bicuculline methiodide; CFE, colony forming efficiency.

Gabrp-mediated signal transduction regulates the proliferation and differentiation of Club cells. A previously published organoid culture method was adopted, which includes a transforming growth factor (TGF)- $\beta$ receptor inhibitor (SB431542) that allows for epithelial clonal expansion. Scgbla1-tagged Club cells were isolated from Scgbla1-mT/mG mice after tamoxifen treatment and maintained in Matrigel cultures for 2 weeks in either the absence or presence of the Gabrp-signaling antagonist BMI. A BMI concentration of $20 \mu \mathrm{g} / \mathrm{ml}$ was previously demonstrated to be sufficient for inhibiting Gabrp signaling in airway cells (20-23). Compared to the control group, the CFE of Club cells was significantly reduced by $\sim 30 \%$ in culture medium supplemented with BMI (Fig. 4A and B) and BMI did not alter the growth of MLg cells (Fig. 4C. These results suggested that BMI may act directly on Club cells.

To further evaluate the role of Gabrp-mediated signaling in Club cell differentiation, Club cells were maintained for 10 days in culture medium containing SB431542 and then switched to culture medium without SB431542. RT-qPCR analysis of total RNA extracted from epithelial organoid 


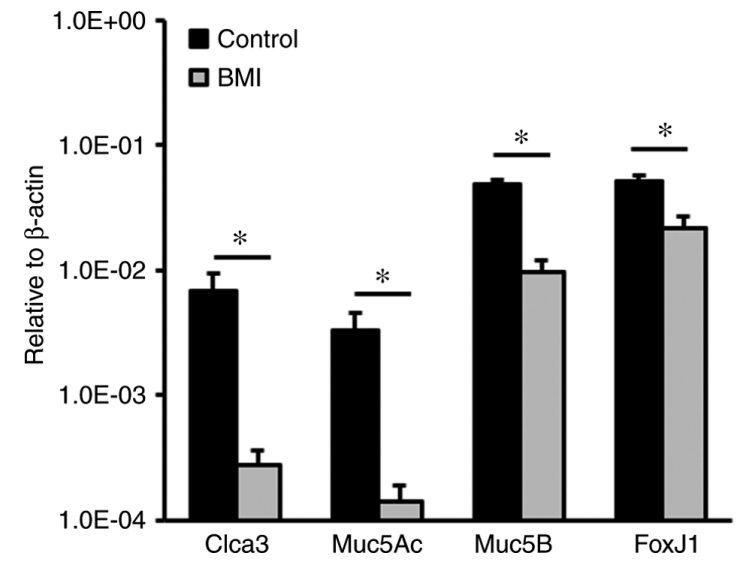

Figure 5. Gamma-aminobutyric acid A receptor pi inhibition reduces goblet cell differentiation. Secretoglobin family 1A member 1-tagged Club cells were cultured and switched to differentiation medium (in the absence of SB431542), followed by reverse transcription-quantitative PCR analysis of the mRNA levels of the indicated genes. ${ }^{*} \mathrm{P}<0.05$. Clca3p, chloride channel accessory 3, pseudogene; Muc, mucin; Fox, forkhead box.

cultures indicated that the mRNA levels of Clca3, Muc5Ac and Muc5B, markers for goblet cells, were significantly decreased in the presence of BMI as compared with those in the control culture (Fig. 5). Of note, the mRNA level of forkhead box protein $\mathrm{J} 1$ was also lower in the BMI-treated group than in the control group, suggesting that blocking Gabrp-mediated signaling inhibits ciliated cell differentiation. These results indicated that Gabrp-mediated signal transduction modulates Club cell differentiation into goblet and ciliated cells.

\section{Discussion}

Mucus overproduction is a major characteristic of bronchial asthma and mucus-producing goblet cells are thought to be generated by airway Club progenitor cells (40-42). Club cells are capable of maintaining the pulmonary epithelium at the steady state and repairing the epithelium after injury (18). The reparative function of Club cells is regulated by their transcriptomes; therefore, in the present study, a transcriptome analysis of Club cells was performed. The results indicated that Gabrp was highly expressed in mouse Club cells, which was validated using both RT-qPCR and in vivo in a mouse model of naphthalene-induced injury. Furthermore, an organoid culture experiment of mouse Club cells suggested that BMI inhibition of Gabrp abrogated Club cell proliferation and goblet cell differentiation. These results suggested that GABA/Gabrp signaling may have a positive role in Club cell function.

A recent study indicated that GABA is able to induce goblet cell hyperplasia in the lungs of primate models and further contribute to the overproduction of airway mucus, leading to the worsening of asthma (16). GABA hypersecretion is necessary for the overproduction of Muc5ac (43) and a study by Xiang et al (44) demonstrated that intravenous injection of the selective GABAA receptor inhibitor BMI suppressed goblet cell hyperplasia and ovalbumin-induced mucus overproduction. In the present study, blocking the GABA/Gabrp signaling pathway with BMI inhibited Club cell differentiation into goblet cells. This result is in agreement with a previous study indicating that GABA contributes to mucus production (44).
In addition, cilia are reportedly disrupted in the airways of patients suffering from asthma (45), and in the present study, it was observed that ciliated cell differentiation was promoted by GABA signaling.

Lung epithelial damage is the initial source of airway inflammation (46). The present study suggested that GABA/Gabrp signaling positively regulated Club cell proliferation, which sustains the pool of Club cells in the airways. In this study, Gabrp enhanced the proliferation of mouse Club cells. The present results support the findings of Xiang et al (44) and provide a more specific cellular mechanism for their observations. As GABA receptors allow the flow of negatively charged $\mathrm{Cl}^{-}$ions across the cell membrane (47), future studies may examine the effects of ion channels on the regulation of Club cell function. The overproduction of airway mucus and the damage to airway epithelia contribute to the chronic airway inflammation occurring in asthma. Therefore, this suggests that GABA/Gabrp signaling may be involved in asthmatic inflammation through multiple mechanisms.

As airway epithelial progenitor cells, Club cells have an important role in host defense by secreting proteins and regenerating airway epithelium after lung injury $(48,49)$. Deregulation of Club cells is closely related to the pathogenesis of diseases involving the conducting airways. Therefore, understanding the signaling pathways that govern Club cell function is critical. Transcriptome analysis of mouse Club cells identified several potential pathways previously demonstrated to be involved in mouse Club cell function, including PTEN and $\beta$-catenin signaling. PTEN acts as a negative regulator of Club cell function, with deletion of PTEN using Nkx2.1-Cre causing both epithelial hyperplasia in the embryonic lung and Club cell expansion in the adult lung owing to the increased proliferative index of Club cells (50). In addition, PTEN silencing contributes to airway remodeling and induces airway smooth muscle cell proliferation in asthma (51). These data suggest a relationship between PTEN and $\beta$-catenin signaling in the regulation of ontogeny. The regeneration of Club cells may be more complex than previously assumed. Consistent with previous studies $(52,53)$, the present pathway analysis indicated that IL-17 signaling is involved in Club cell function. Conditional loss of the TGF- $\beta$ type 1 receptor using Gata5-Cre in the embryonic lung epithelium blocked Club cell differentiation (54). However, previous in vitro culture data demonstrated that blockade of TGF- $\beta$ signaling with the selective inhibitor SB431542 promoted airway progenitor cell proliferation (19).

Pathway analysis of Club cells suggested several other novel signaling pathways that may regulate Club cell proliferation and/or differentiation. Other potential pathways included AHR signaling, acute phase response signaling and nuclear factor, erythroid 2 like 2-mediated oxidative stress response signaling. Of note, transcriptome analysis proposed a number of metabolic pathways that may affect mouse Club cell function, including glutathione metabolism, fatty acid metabolism and pyruvate metabolism. Future studies are required to investigate the impact of metabolism on Club cell function at the steady state and in the pathology of asthma.

In conclusion, GABA induces hyperplasia of goblet cells. The present results revealed that Gabrp is expressed in mouse airway progenitor cells and that the Gabrp inhibitor BMI 
reduced their proliferation and goblet cell differentiation. Therefore, targeting GABA/Gabrp signaling may represent a promising strategy for treating goblet cell hyperplasia in bronchial asthma.

\section{Acknowledgements}

Not applicable.

\section{Funding}

This study was supported by the National Natural Science Foundation of China (grant nos. 81773394, 81970001 and 82070001), the Natural Science Foundation of Tianjin (grant nos. 18ZXDBSY00150, 19JCZDJC33600 and 20JCQNJC01790), Tianjin Health Science and Technology Project (grant no. 2020XKZ02) and the Science and Technology Fund of Tianjin Haihe Hospital (grant nos. HHYY-202008 and HHYY-202012).

\section{Availability of data and materials}

The datasets generated and/or analyzed during the current study are not publicly available due to the transcriptome data being needed for other research but are available from the corresponding author on reasonable request.

\section{Authors' contributions}

AW, QZ, YW, XL, LL and HC designed the experiments and wrote the manuscript with input from co-authors. AW and QZ performed the experiments. XL, KL, YL and JW preformed the animal studies. All authors discussed the results and commented on the manuscript. AW and HC confirmed the authenticity of all the raw data. All authors read and approved the final manuscript.

\section{Ethics approval and consent to participate}

All mice were treated with strict adherence to the protocol (no. 2020HHSQKT-001) that was approved by the Haihe Hospital Animal Care and Use Committee.

\section{Patient consent for publication}

Not applicable.

\section{Competing interests}

The authors declare that they have no competing interests.

\section{References}

1. Gon Y and Hashimoto S: Role of airway epithelial barrier dysfunction in pathogenesis of asthma. Allergol Int 67: 12-17, 2018.

2. Lam M, Lamanna E and Bourke JE: Regulation of airway smooth muscle contraction in health and disease. Adv Exp Med Biol 1124: 381-422, 2019

3. Murrison LB, Brandt EB, Myers JB and Hershey GKK: Environmental exposures and mechanisms in allergy and asthma development. J Clin Invest 129: 1504-1515, 2019.
4. Evans CM, Williams OW, Tuvim MJ, Nigam R, Mixides GP, Blackburn MR, DeMayo FJ, Burns AR, Smith C, Reynolds SD, et al: Mucin is produced by clara cells in the proximal airways of antigen-challenged mice. Am J Respir Cell Mol Biol 31: 382-394, 2004.

5. Reynolds SD, Reynolds PR, Pryhuber GS, Finder JD and Stripp BR: Secretoglobins SCGB3A1 and SCGB3A2 define secretory cell subsets in mouse and human airways. Am J Respir Crit Care Med 166: 1498-1509, 2002.

6. Singh G and Katyal SL: Clara cell proteins. Ann N Y Acad Sci 923: 43-58, 2000.

7. Tam A, Wadsworth S, Dorscheid D, Man SF and Sin DD: The airway epithelium: More than just a structural barrier. Ther Adv Respir Dis 5: 255-273, 2011.

8. El-Badrawy MK, Shalabi NM, Mohamed MA, Ragab A and Abdelwahab HW: Stem cells and lung regeneration. Int J Stem Cells 9: 31-35, 2016.

9. Porotto M, Ferren M, Chen YW, Siu Y, Makhsous N, Rima B, Briese T, Greninger AL, Snoeck HW and Moscona A: Authentic modeling of human respiratory virus infection in human pluripotent stem cell-derived lung organoids. mBio 10: e00723-19, 2019.

10. Sacco O, Silvestri M, Sabatini F, Sale R, Defilippi AC and Rossi GA: Epithelial cells and fibroblasts: Structural repair and remodelling in the airways. Paediatr Respir Rev 5 (Suppl A): S35-S40, 2004.

11. Samitas K, Carter A, Kariyawasam HH and Xanthou G: Upper and lower airway remodelling mechanisms in asthma, allergic rhinitis and chronic rhinosinusitis: The one airway concept revisited. Allergy 73: 993-1002, 2018.

12. McCauley KB, Alysandratos KD, Jacob A, Hawkins F, Caballero IS, Vedaie M, Yang W, Slovik KJ, Morley M, Carraro G, et al: Single-cell transcriptomic profiling of pluripotent stem cell-derived SCGB3A2+ airway epithelium. Stem Cell Reports 10: 1579-1595, 2018.

13. Parekh KR, Nawroth J, Pai A, Busch SM, Senger CN and Ryan AL: Stem cells and lung regeneration. Am J Physiol Cell Physiol 319: C675-C693, 2020.

14. Barkauskas CE, Chung MI, Fioret B, Gao X, Katsura H and Hogan BL: Lung organoids: Current uses and future promise. Development 144: 986-997, 2017.

15. Boers JE, Ambergen AW and Thunnissen FB: Number and proliferation of clara cells in normal human airway epithelium. Am J Respir Crit Care Med 159: 1585-1591, 1999.

16. Barrios J, Kho AT, Aven L, Mitchel JA, Park JA, Randell SH, Miller LA, Tantisira KG and Ai X: Pulmonary neuroendocrine cells secrete gamma-aminobutyric acid to induce goblet cell hyperplasia in primate models. Am J Respir Cell Mol Biol 60: 687-694, 2019.

17. Song H, Yao E, Lin C, Gacayan R, Chen MH and Chuang PT: Functional characterization of pulmonary neuroendocrine cells in lung development, injury, and tumorigenesis. Proc Natl Acad Sci USA 109: 17531-17536, 2012.

18. Li K, Li M, Li W, Yu H, Sun X, Zhang Q, Li Y, Li X, Li Y, Abel ED, et al: Airway epithelial regeneration requires autophagy and glucose metabolism. Cell Death Dis 10: 875, 2019.

19. Teisanu RM, Chen H, Matsumoto K, McQualter JL, Potts E, Foster WM, Bertoncello I and Stripp BR: Functional analysis of two distinct bronchiolar progenitors during lung injury and repair. Am J Respir Cell Mol Biol 44: 794-803, 2011.

20. Barolet AW, Li A, Liske S and Morris ME: Antagonist actions of bicuculline methiodide and picrotoxin on extrasynaptic gamma-aminobutyric acid receptors. Can J Physiol Pharmacol 63: 1465-1470, 1985

21. Hussin AT, Boychuk JA, Brown AR, Pittman QJ and Teskey GC: Intracortical microstimulation (ICMS) activates motor cortex layer 5 pyramidal neurons mainly transsynaptically. Brain Stimul 8: 742-750, 2015.

22. Johnson SW and Seutin V: Bicuculline methiodide potentiates NMDA-dependent burst firing in rat dopamine neurons by blocking apamin-sensitive $\mathrm{Ca} 2+$-activated $\mathrm{K}+$ currents. Neurosci Lett 231: 13-16, 1997.

23. Uva L, Boido D, Avoli M, de Curtis $M$ and Lévesque M: High-frequency oscillations and seizure-like discharges in the entorhinal cortex of the in vitro isolated guinea pig brain. Epilepsy Res 130: 21-26, 2017.

24. Chen H, Matsumoto K, Brockway BL, Rackley CR, Liang J, Lee JH, Jiang D, Noble PW, Randell SH, Kim CF and Stripp BR: Airway epithelial progenitors are region specific and show differential responses to bleomycin-induced lung injury. Stem Cells 30: 1948-1960, 2012. 
25. Chen H, Sun X, Chi R, Li X, Feng J, Wu J, Ning W, Liu Z and Wu Q: Glucocorticoid dexamethasone regulates the differentiation of mouse conducting airway epithelial progenitor cells. Steroids 80: 44-50, 2014

26. Li X, Wang YM, Wang A, Li Y, Wu Q and Chen HY: Sex-determining region Y-box 2-positive alveolar cells are responsive to bleomycin-induced lung injury. Chin Med J (Engl) 134: 234-236, 2020.

27. Davé V, Wert SE, Tanner T, Thitoff AR, Loudy DE and Whitsett JA: Conditional deletion of Pten causes bronchiolar hyperplasia. Am J Respir Cell Mol Biol 38: 337-345, 2008.

28. Reynolds SD, Zemke AC, Giangreco A,Brockway BL, Teisanu RM, Drake JA, Mariani T, Di PY, Taketo MM and Stripp BR: Conditional stabilization of beta-catenin expands the pool of lung stem cells. Stem Cells 26: 1337-1346, 2008.

29. Carratt SA, Kovalchuk N, Ding X and Van Winkle LS: Metabolism and lung toxicity of inhaled naphthalene: Effects of postnatal age and sex. Toxicol Sci 170: 536-548, 2019.

30. Plopper CG, Van Winkle LS, Fanucchi MV, Malburg SR, Nishio SJ, Chang A and Buckpitt AR: Early events in naphthalene-induced acute clara cell toxicity. II. Comparison of glutathione depletion and histopathology by airway location. Am J Respir Cell Mol Biol 24: 272-281, 2001.

31. Kang BH, Manderschied BD, Huang YC, Crapo JD and Chang LY: Contrasting response of lung parenchymal cells to instilled TNF alpha and IFN gamma: The inducibility of specific cell ICAM-1 in vivo. Am J Respir Cell Mol Biol 15: 540-550, 1996.

32. Sturrock A, Seedahmed E, Mir-Kasimov M, Boltax J, McManus ML and Paine R III: GM-CSF provides autocrine protection for murine alveolar epithelial cells from oxidant-induced mitochondrial injury. Am J Physiol Lung Cel Mol Physiol 302: L343-L351, 2012.

33. Sugahara K, Freidenberg GR and Mason RJ: Insulin binding and effects on glucose and transepithelial transport by alveolar type II cells. Am J Physiol 247: C472-C477, 1984.

34. Xu Y, Ikegami M, Wang Y, Matsuzaki Y and Whitsett JA: Gene expression and biological processes influenced by deletion of Stat 3 in pulmonary type II epithelial cells. BMC Genomics 8 : $455,2007$.

35. Bokoch GM: Biology of the p21-activated kinases. Annu Rev Biochem 72: 743-781, 2003.

36. Gakhar L, Bartlett JA, Penterman J, Mizrachi D, Singh PK, Mallampalli RK, Ramaswamy S and McCray PB Jr: PLUNC is a novel airway surfactant protein with anti-biofilm activity. PLoS One 5: e9098, 2010.

37. Sountoulidis A, Liontos A, Nguyen HP, Firsova AB Fysikopoulos A, Qian X, Seeger W, Sundström E, Nilsson M and Samakovlis C: SCRINSHOT enables spatial mapping of cell states in tissue sections with single-cell resolution. PLoS Biol 18 e3000675, 2020

38. Zemke AC, Snyder JC, Brockway BL, Drake JA, Reynolds SD, Kaminski N and Stripp BR: Molecular staging of epithelial maturation using secretory cell-specific genes as markers. Am J Respir Cell Mol Biol 40: 340-348, 2009.

39. Manzo ND, Foster WM and Stripp BR: Amphiregulin-dependent mucous cell metaplasia in a model of nonallergic lung injury. Am J Respir Cell Mol Biol 47: 349-357, 2012.

40. Lambrecht $\mathrm{BN}$ and Hammad $\mathrm{H}$ : The airway epithelium in asthma. Nat Med 18: 684-692, 2012.
41. Reader JR, Tepper JS, Schelegle ES, Aldrich MC, Putney LF, Pfeiffer JW and Hyde DM: Pathogenesis of mucous cell metaplasia in a murine asthma model. Am J Pathol 162: 2069-2078, 2003.

42. Chen G, Korfhagen TR, Xu Y, Kitzmiller J, Wert SE, Maeda Y, Gregorieff A, Clevers $\mathrm{H}$ and Whitsett JA: SPDEF is required for mouse pulmonary goblet cell differentiation and regulates a network of genes associated with mucus production. J Clin Invest 119: 2914-2924, 2009.

43. Barrios J, Patel KR, Aven L, Achey R, Minns MS, Lee Y, Trinkaus-Randall VE and Ai X: Early life allergen-induced mucus overproduction requires augmented neural stimulation of pulmonary neuroendocrine cell secretion. FASEB J 31: 4117-4128, 2017

44. Xiang YY, Wang S, Liu M, Hirota JA, Li J, Ju W, Fan Y, Kelly MM, Ye B, Orser B, et al: A GABAergic system in airway epithelium is essential for mucus overproduction in asthma. Nat Med 13: 862-867, 2007.

45. Fireman P: Understanding asthma pathophysiology. Allergy Asthma Proc 24: 79-83, 2003.

46. Khair OA, Davies RJ and Devalia JL: Bacterial-induced release of inflammatory mediators by bronchial epithelial cells. Eur Respir J 9: 1913-1922, 1996.

47. Jin N, Guo Y, Sun P, Bell A, Chintagari NR, Bhaskaran M, Rains K, Baviskar P, Chen Z, Weng T and Liu L: Ionotropic GABA receptor expression in the lung during development. Gene Expr Patterns 8: 397-403, 2008.

48. Malvin NP, Kern JT, Liu TC, Brody SL and Stappenbeck TS: Autophagy proteins are required for club cell structure and function in airways. Am J Physiol Lung Cell Mol Physiol 317: L259-L270, 2019.

49. Shafiquzzaman M, Biswas S, Li P, Mishina Y, Li B and Liu H: The noncanonical BMP signaling pathway plays an important role in club cell regeneration. Stem Cells 38: 437-450, 2020.

50. Tiozzo C, De Langhe S, Yu M, Londhe VA, Carraro G, Li M, Li C, Xing Y, Anderson S, Borok Z, et al: Deletion of Pten expands lung epithelial progenitor pools and confers resistance to airway injury. Am J Respir Crit Care Med 180: 701-712, 2009.

51. Wen X, Yan J, Han XR, Zheng GH, Tang R, Liu LF, Wu DM, $\mathrm{Lu} \mathrm{J}$ and Zheng YL: PTEN gene silencing contributes to airway remodeling and induces airway smooth muscle cell proliferation in mice with allergic asthma. J Thorac Dis 10: 202-211, 2018.

52. Kreindler JL, Bertrand CA, Lee RJ, Karasic T, Aujla S, Pilewski JM, Frizzell RA and Kolls JK: Interleukin-17A induces bicarbonate secretion in normal human bronchial epithelial cells. Am J Physiol Lung Cell Mol Physiol 296: L257-L266, 2009.

53. McAllister F, Henry A, Kreindler JL, Dubin PJ, Ulrich L, Steele C, Finder JD, Pilewski JM, Carreno BM, Goldman SJ, et al: Role of IL-17A, IL-17F, and the IL-17 receptor in regulating growth-related oncogene-alpha and granulocyte colony-stimulating factor in bronchial epithelium: Implications for airway inflammation in cystic fibrosis. J Immunol 175: 404-412, 2005.

54. Xing Y, Li C, Li A, Sridurongrit S, Tiozzo C, Bellusci S, Borok Z, Kaartinen V and Minoo P: Signaling via Alk5 controls the ontogeny of lung clara cells. Development 137: 825-833, 2010.

This work is licensed under a Creative Commons

Attribution-NonCommercial-NoDerivatives 4.0

International (CC BY-NC-ND 4.0) License. 